\title{
INFESTATION AND DISTRIBUTION OF THE MITE Varroa destructor IN COLONIES OF AFRICANIZED BEES
}

\author{
MORETTO, G. and LEONIDAS, J. de M. \\ Departamento de Ciências Naturais, Universidade Regional de Blumenau, \\ CEP 89010-971, Blumenau, SC, Brazil \\ Correspondence to: Geraldo Moretto, Departamento de Ciências Naturais, Universidade Regional de \\ Blumenau, CEP 89010-971, Blumenau, SC, Brazil, e-mail: gmoretto@ furb.br \\ Received January 9, 2001 - Accepted August 6, 2001 - Distributed February 28, 2003
}

\begin{abstract}
Whereas in several parts of the world varroa is the major pest affecting apiculture, in others the parasite is unknown to many beekeepers because its damage to bees is minor. The impact of the mite Varroa destructor is related to the climatic conditions and the races of Apis mellifera bees in each region where the pest exists. In the present study, the current level of infestation by the mite was assessed to determine the evolution of the pest in Africanized bee colonies in Southern Brazil. This level of infestation was considered low: approximately two mites per one hundred adult bees. This result is similar to that obtained for the same apiary almost five years ago and for others distributed in various regions of Brazil. In the present study, we also estimated the total varroa population and its distribution among brood and adults in each bee colony.
\end{abstract}

Key words: Varroa destructor, Africanized bees, tolerance, infestation, distribution.

\section{RESUMO}

\section{Infestação e distribuição do ácaro Varroa destructor em colônias de abelhas africanizadas}

Enquanto em diversas partes do mundo a varroa é considerada a mais preocupante peste que afeta a apicultura, em outras o parasita é desconhecido de muitos apicultores em razão dos poucos danos causados às abelhas. $\mathrm{O}$ impacto do ácaro Varroa destructor está relacionado às condições climáticas e à raça de abelhas Apis mellifera em cada região onde a praga se estabeleceu. No presente estudo foram avaliadas a evolução da varroatose e a distribuição do ácaro Varroa destructor em colônias de abelhas africanizadas no sul do Brasil. O grau de infestação alcançado pela praga varroatose nas colônias de abelhas envolvidas neste trabalho foi de aproximadamente dois ácaros para cada cem abelhas. Esta infestação é semelhante à encontrada no mesmo apiário e em outros de várias regiões do Brasil aproximadamente cinco anos atrás. Neste estudo também foram avaliadas a população total de varroas e a sua distribuição entre as crias e as abelhas adultas.

Palavras-chave: Varroa destructor, abelhas africanizadas, tolerância, infestação, distribuição.

\section{INTRODUCTION}

The mite Varroa destructor, an ectoparasite of Apis cerana and Apis mellifera brood and adults, was prevoiusly limited to only some regions of the world where it was parasitized its ingle original host, i.e., the species cerana, without causing damage to apiculture. The parasite-host relationship between Apis cerana and varroa seemed to have reached equilibrium because of the development of defense mechanisms by this bee species against the parasite (Peng et al., 1987).

The contact of varroa with Apis mellifera, which occurred possibly at the end of the fifties, was characterized by rapid dispersal of the pest. Today the parasite infests many countries in Europe, Africa, Asia, and America.

Apiculture started to feel a strong impact due to the drastic effects of varroatosis in various world regions, with high rates of brood and adult bee 
infestation in colonies of Apis mellifera bees (De Jong, 1984).

To minimize the effects of varroa infestation on Apis mellifera, several acaricides were developed by various chemical companies. However, thus far no chemical product has succeeded fully in eradicating the pest. On the contrary, cases of development of resistance to certain acaricides by Varroa destructor have been observed (Boot et al., 1995).

The effects of varroa infestation on Apis mellifera appear at different intensities in the various regions of the world where the parasite has become established. In general, bees of African races and their hybrids show more tolerance to Varroa destructor, with no serious losses for apiculture (De Jong et al., 1984; Montiel \& Piola, 1976).

The reproductive process of Varroa destructor starts when the adult female parasite abandons an adult worker bee or drone and penetrates worker or drone brood cells (GusmanNovoa et al., 1999).

These cells, of Apis cerana and Apis mellifera, are invaded when the bee brood reaches the last larval stage, a few moments before cell operculation (De Jong, 1997). Thus, when bee colonies are in normal conditions (a good number of brood and adults), the varroa population is distributed among adult bees and brood.

The objective of the present study was to evaluate the evolution of varroatosis and the distribution of the varroa population inside colonies of Africanized bees.

\section{MATERIALS AND METHODS}

The study was conducted using eight nuclei of Africanized bees from the experimental apiary of the Department of Natural Sciences, Regional University of Blumenau, State of Santa Catarina, Brazil, at $17 \mathrm{~m}$ altitude and $26^{\circ} 55^{\prime} 10^{\prime}$ ' latitude south.

To evaluate the distribution of varroa on brood cells and adult bees in each bee colony, first the total number of brood and adult bees was estimated.

\section{Estimate of adult bee population}

To estimate the population of adult bees, each bee colony was weighed twice. The first weighing was performed during the day and was of each hive with no adult bees inside. During the night of this same day, each colony was weighed when containing the adult bees and respective material. The difference between these weights provided the net weight of the adult bees in the colony.

Five samples of 100 adult bees from each colony were weighed on a Master scale with 0.5 precision. Using the mean weight of these samples and the adult bee weight of each colony, the population of adult bees was estimated using the following expression:

$$
y=a . b / c,
$$

where:

$$
\begin{aligned}
& \mathrm{y}=\text { population of adult bees } \\
& \mathrm{a}=100 \text { adult bees } \\
& \mathrm{b}=\text { weight of adult bee population } \\
& \mathrm{c}=\text { mean weight of } 100 \text { adult bees }
\end{aligned}
$$

\section{Estimate of the number of capped brood in the last larval stage}

The combs containing capped broods in the last larval stage were measured using a support comb with a $1 \mathrm{~cm}^{2}$ mesh wire net. To determine their total, the number of cells with brood was counted in 20 areas of each colony. The total cell number was estimated by multiplying the number of colony areas with brood by the mean number of cells per area.

\section{Estimate of number of varroas on adult bees}

Five samples of 200 to 300 adult bees were collected on alternate days from each hive. The method of De Jong et al. (1982) was used to estimate the number of mites per adult bee. The population of varroas on the adult bees was obtained by multiplying the mean number occurring in the five samples by the total number of adult bees.

\section{Estimate of number of varroas in the brood}

Five hundred cells per bee colony were uncapped and the number of varroas was counted. The total number of mites was estimated using the following expression:

$$
x=a . b / c,
$$

where:

$$
\begin{aligned}
\mathrm{x}= & \text { number of varroas on the brood } \\
\mathrm{a}= & \text { total number of cells with brood } \\
\mathrm{b}= & \begin{array}{l}
\text { number of varroas in the } 500 \text { cells } \\
\text { analyzed }
\end{array}
\end{aligned}
$$


$\mathrm{c}=500$ cells analyzed

The total number of varroas in each bee colony was obtained by the sum of the estimated number of varroas detected on brood and adult bees.

\section{RESULTS AND DISCUSSION}

The mite Varroa destructor has been infesting Africanized bees in Brazil for almost 30 years. Soon after its discovery, although there were no reports of bee colony deaths, the levels of infestations detected were a source of concern for Brazilian apiculture. However, as the pest started to disperse through the country, the infestation level of varroa on Africanized bees was found to be low, causing no apparent harm to apiculture and requiring no use of chemical products to combat the pest.

The climatic conditions of Brazil, together with various mechanisms present in Africanized bees, render these bees tolerant to the mite Varroa destructor (Camazine, 1986; Moretto et al., 1993; De Jong \& Soares, 1997).

The degree of infestation estimated in the present study was $2.33 \pm 0.83 \%$ (mean and standard deviation) for adult bees and $5.06 \pm 2.47 \%$ for brood.

The bee colonies studied here are part of an experimental apiary set up in 1992. Some of these colonies were collected from natural swarms while others were the result of the swarm division process. The mean mite infestation in the bees of this apiary was $1.78 \%$ in 1995 (Moretto et al., 1995). Thus, almost five years later, the varroa infestation of this apiary continued unchanged and low-level.

The total varroa population (estimated number of varroas on adult bees and brood) in the colonies studied was on average $724 \pm 419$ (mean and standard deviation) mites per bee colony. Although the present study was conducted on hives of the nucleus type (four combs) and, therefore, with a limited number of adult bees and brood in a restricted brood area, the varroa population can be considered low for the period of time during which these bee colonies have been in contact with the parasite, with no type of treatment for pest control.

It is known that, to complete their reproductive cycle, adult varroa females abandon adult bees and invade worker and drone brood cells. Of the total varroa population in the colonies studied here, an average of $61 \%$, were found on worker brood.
Although thus far there is no mechanism explaining why the varroa leaves an adult bee to invade brood cells, it is known that the number of varroas on brood is related to the season of the year and availability of brood in the hive (Boot et al., 1994a; Eguaras et al., 1994). According to Boot et al. (1994b), the mite enters a brood cell immediately after abandoning the body of an adult bee. Varroas moving on the comb have never been observed, showing that the mite does not look for a specific brood cell to invade.

The number of descendants that varroa females can leave on Africanized bees is smaller than that found among bees of European races (Medina \& Martin, 1999). It is also known that Brazilian Africanized bees when artificially parasitized with adult varroa females can rid themselves of the parasite through vigorous body movement, a behavior called grooming (Moretto $\&$ Mello, 1999). This behavior of Africanized bees is also observed under natural conditions, i.e., workers can be seen performing body movements when infested with varroas. According to Boot et al. (1995), the Africanized bees of Brazil, Apis cerana in Asia, and Apis mellifera intermissa in Africa present this grooming behavior and varroa females infesting them do not leave descendants when parasitizing worker brood cells.

The high percentage of mites on worker brood of Africanized bees detected in the present study may also be associated with the grooming behavior of these bees, which causes the varroa to look for brood as a defence against worker attack, instead of leaving the adult bees, and to invade the brood to perform its reproductive cycle. This may be one of the causes of the small number of descendants produced by Varroa destructor on Africanized bees. However, new studies should be conducted to determine the distribution of the mite Varroa destructor in Apis mellifera colonies of European races.

Acknowledgments -- The authors thank Arnor Bublitz Filho and Denilson Bittencourt for help in the apiary.

\section{REFERENCES}

BOOT, J., BAALEN, M. \& SABELIS, M. W., 1995, Why do Varroa mites invade worker brood cells of the honey bee despite lower reproductive success? Bhev. Ecol. Sociobiol., 36: 283-289. 
BOOT, J., BEETSMA, J. \& CALIS, J. N. M., 1994b, Behavior of Varroa mites invading bee brood cells. Experimental \& Applied Acarology, 18: 371-379.

BOOT, J., SISSELAR, D. J. A., CALIS, J. N. M. \& BEETSMA, J., 1994 a, Factors affecting invasion of Varroa jacobsoni (Acari: Varroidae) into honeybee, Apis mellifera (hymenoptera: Apidade), brood cells. Bull. Entomol. Res., 84: 3-10.

CAMAZINE, S., 1986, Differential reproduction of Varroa jacobsoni, on Africanized and European honeybees. Ann. Entomol. Soc. Am., 79: 801-803.

DE JONG, D., 1997, Mites: Varroa and other parasites of brood. In: R. A. Morse \& K. Flottum (eds.), Honey bee pest, predators and diseases. The A. I. Root Company, $\mathrm{OH}$, pp. 279-328.

DE JONG, D., 1984, Current knowledge and open question concerning reproduction in honey bee mite Varroa jacobsoni. Advances in Invertebrate Reproduction, 3: 347-352.

DE JONG, D., GONÇALVES, L. S. \& MORSE, R. A., 1984, Dependence of climate on the virulence of Varroa jacobsoni. Bee World, 65: 117-121.

DE JONG, D., ROMA, D. A. \& GONÇALVES, L. S., 1982, A comparative analysis of shaking solutions for the detection of Varroa jacobsoni on adult honey bees. Apidologie, 13: 297-306.

DE JONG, D. \& SOARES, A. E. E., 1997, An isolated population of Italian bees that survived Varroa jacobsoni infestation without treatment for over 12 years. American Bee Journal., 137: 742-745.

EGUARAS, M., MARCANGELI, J., OPPEDISANO, M. \& FERNANDES, N., 1994, Seasonal changes in Varroa jacobsoni Oud. Reproduction in temperate climate of Argentina. Bee Science, 3(3): 120-123.
GUSMAN-NOVOA, E., VALDAME, R., ARECHAVALETA, M. E. \& SANCHES, A., 1999, Susceptibility of European and Africanized bees (Apis mellifera L.) to Varroa jacobsoni Oud. Apidologie, 30: 173-182.

MEDINA, L. M. \& MARTIN, S. J., 1999, A comparative study of Varroa jacobsoni reproduction in worker cells of honey bees (Apis mellifera) in England and Africanized bees in Yucatan, Mexico. Experimental \& Applied Acarology, 23: 659-667.

MONTIEL, E. J. C. \& PIOLA, G. A., 1976, A new enemy of bees. In: V. Harnaj (ed.), Varroasis a honey bee disease. Apimondia Publishing House, Bucharest, pp. 3638.

MORETTO, G. \& MELLO, J. L., 1999, Varroa jacobsoni infestation of adult Africanized and Italian bees (Apis mellifera) in mixed colonies in Brazil. Genetics and Molecular Biology, 22: 321-323.

MORETTO, G., GONÇALVES, L. S. \& DE JONG, D., 1993, Heritability of Africanized and European honeybee defensive behavior against the mite Varroa jacobsoni. Revista Brasileira de Genética, 16: 71-77.

MORETTO, G., PILATTI, A., DE JONG, D., GONÇALVES, L. S. \& CASSINI, F., 1995, Reduction of Varroa jacobsoni in the State of Santa Catarina, in Southern of Brazil. American Bee Journal, 135: 498-500.

PENG, Y. S., FANG, Y., XU, S. \& GE, L., 1987, The resistence mechanism of the Asia honeybee Apis cerana Fabr. to an ectoparasite mite Varroa jacobsoni Oudemanas. J. Invert. Pathol., 19: 54-60. 